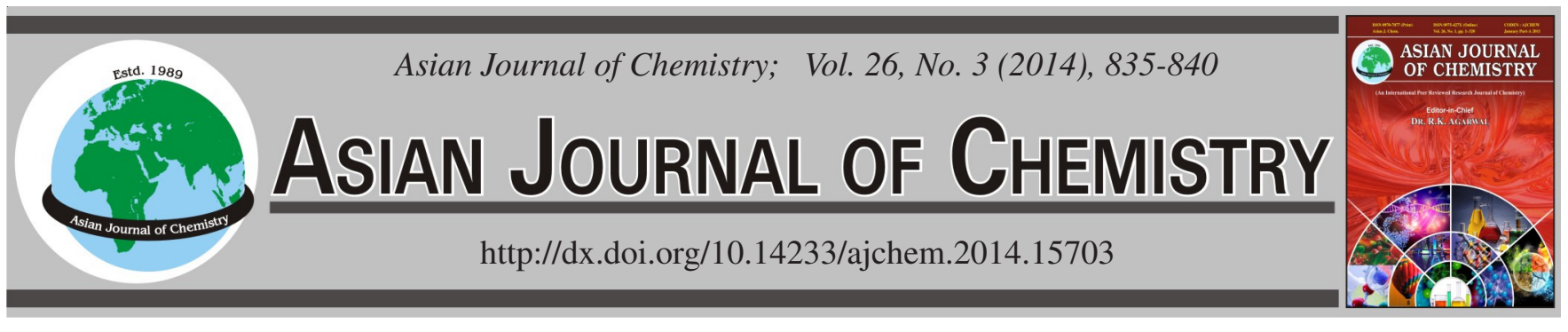

\title{
Effect of Unitary, Binary and Ternary Carboxylates on Crystallization Kinetics of Calcium Oxalate in Artificial Urine
}

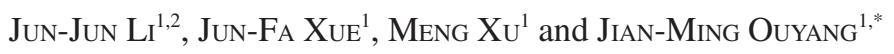

${ }^{1}$ Institute of Biomineralization and Lithiasis Research, Jinan University, Guangzhou 510632, P.R. China

${ }^{2}$ College of Pharmacy, Guangdong Pharmaceutical University, Guangzhou 510006, P.R. China

*Corresponding author: E-mail: toyjm@jnu.edu.cn

Received: 19 April 2013;

Accepted: 17 September 2013;

Published online: 30 January 2014;

AJC-14649

\begin{abstract}
The effect of three types of carboxylates on the crystallization kinetics of calcium oxalate $\left(\mathrm{CaC}_{2} \mathrm{O}_{4}\right)$ were studied by detecting the change of free $\mathrm{Ca}^{2+}$ ions concentration, size of $\mathrm{CaC}_{2} \mathrm{O}_{4}$ crystallites, zeta potential, autocorrelation curve and decay time with reaction time ( $\mathrm{t}$ ) in artificial urine. Sodium glycinate (NaGly; a monocarboxylate), sodium tartrate $\left(\mathrm{Na}_{2} \mathrm{Tart}\right.$; a dicarboxylate) and sodium citrate $\left(\mathrm{Na}_{3} \mathrm{Cit}\right.$; a tricarboxylate) were the three carboxylates investigated in this study. The crystallization kinetics equation of $\mathrm{CaC}_{2} \mathrm{O}_{4}$ was $\mathrm{r}=\mathrm{kc}^{3.3}$ and the average reaction rate constant $(\overline{\mathrm{k}})$ was $0.99 \times 10^{9}$. All the three carboxylates could inhibit the kinetics process of nucleation, growth and aggregation of $\mathrm{CaC}_{2} \mathrm{O}_{4}$ crystallites. In the presence of various carboxylate, the value is arranged from smallest to largest in the following order $\mathrm{Na}_{3} \mathrm{Cit}\left(2.29 \times 10^{5}\right)<\mathrm{Na}_{2}$ Tart $\left(9.76 \times 10^{5}\right)<\mathrm{NaGly}\left(1.68 \times 10^{7}\right)<$ Blank $\left(0.99 \times 10^{9}\right)$. The changes in size, zeta potential and decay time of the crystallites can also be arranged in the following order: $\mathrm{Na}_{3} \mathrm{Cit}<\mathrm{Na}_{2}$ Tart $<\mathrm{NaGly}<$ blank.
\end{abstract}

Keywords: Calcium oxalate, Crystallization kinetics, Carboxylate, Reaction order, Autocorrelation decay time.

\section{INTRODUCTION}

Urolithiasis is a chronic disease with an incidence increasing annually, may relapse after treatment ${ }^{1}$. Calcium oxalate $\left(\mathrm{CaC}_{2} \mathrm{O}_{4}\right)$ is the main component of urinary stones. Stone formation involves nucleation, growth, aggregation and adhesion process of urinary crystallites.

The complexity of the internal environment in the human body, observing the formation processes of stones in situ is difficult. Therefore, we usually use the simulative method in vitro to study the nucleation, growth and aggregation of $\mathrm{CaC}_{2} \mathrm{O}_{4}$ and the influence of various inhibitors on these processes $^{1}$. These simulative systems contain water, urine, artificial urine, membrane mimetic system, surface of renal epithelial cells, etc ${ }^{2-5}$.

Nishio et al. ${ }^{6}$ studied the inhibition effects of prothrombin fragment 1 and osteopontin on $\mathrm{CaC}_{2} \mathrm{O}_{4}$ crystallization in artificial urine, indicating that the inhibition effects of the two proteins on the growth rate of $\mathrm{CaC}_{2} \mathrm{O}_{4}$ were 27 and $32 \%$, respectively, when their concentration were $2 \mu \mathrm{g} / \mathrm{mL}$. Wang et al. ${ }^{7}$ studied the inhibition effect of phosphorylated osteopontin segment on nucleation and growth of calcium oxalate monohydrate (COM) crystals under near-physiological $\mathrm{pH}$, temperature and ionic strength. When the concentration of phosphorylated OPN was $43.9 \mathrm{~nm}$, the growth rate of $\mathrm{CaC}_{2} \mathrm{O}_{4} \cdot \mathrm{H}_{2} \mathrm{O}$ crystals was only $60 \%$ of the control group. When the concentration of phosphorylated OPN reached $108.0 \mathrm{~nm}$, the growth inhibition of $\mathrm{CaC}_{2} \mathrm{O}_{4} \cdot \mathrm{H}_{2} \mathrm{O}$ crystals was $93 \%$. By contrast, the inhibition of un-phosphorylated OPN on the growth of $\mathrm{CaC}_{2} \mathrm{O}_{4} \cdot \mathrm{H}_{2} \mathrm{O}$ crystals was not significant. Even when the concentration reached $1450 \mathrm{~nm}$, the inhibition of un-phosphorylated OPN did not show a significant effect. The reason for this phenomenon is that the doubly phosphorylated peptide binds strongly to both ( $\overline{101})$ and (010) faces of $\mathrm{CaC}_{2} \mathrm{O}_{4} \cdot \mathrm{H}_{2} \mathrm{O}$, thus inhibiting the growth of $\mathrm{CaC}_{2} \mathrm{O}_{4} \cdot \mathrm{H}_{2} \mathrm{O}$ crystals. Carvalho et al. ${ }^{8}$ studied the effect of $\mathrm{CaC}_{2} \mathrm{O}_{4}$ relative saturation ( $\mathrm{RS}$ ) on $\mathrm{CaC}_{2} \mathrm{O}_{4}$ crystallization in urine. At $\mathrm{RS}<10$, no crystal was formed in the urine; at RS of 10, small crystals formed into COD; at RS of 30, the number of crystals with the same size increased; at RS greater than 50 , the crystal size increased and a large amount of crystals aggregated. These patterns indicate that the RS of $\mathrm{CaC}_{2} \mathrm{O}_{4}$ and calcium to oxalate ratio $(\mathrm{Ca} / \mathrm{Ox})$ in urine are important factors in determining the structure and morphology of $\mathrm{CaC}_{2} \mathrm{O}_{4}$ crystals.

Although studying the calculus formation mechanism in real urine environment is ideal, but storing real urine is difficult. In addition, real urine does not meet the dosage test requirement. Therefore, artificial urine is widely used. For example, Beghalia et al. ${ }^{9}$ studied the effect of ajuga and atriplex, which are two types of herbal medicine, on $\mathrm{CaC}_{2} \mathrm{O}_{4}$ crystallization in 
artificial urine. They denoted that ajuga and atriplex could inhibit both nucleation and growth of $\mathrm{CaC}_{2} \mathrm{O}_{4}$. Patel et al. ${ }^{10}$ studied the effect of lactic acid and citric acid on the solubility of $\mathrm{CaC}_{2} \mathrm{O}_{4}$ crystals in artificial urine. With increasing concentration, the soluble calcium ion concentration in the solution increased. When the concentration of two substances is equal, the ability of lactic acid to dissolve $\mathrm{CaC}_{2} \mathrm{O}_{4}$ crystals is greater than that of citric acid and the maximum dissolved amount could reach $70 \%$ of the $\mathrm{CaC}_{2} \mathrm{O}_{4}$ crystals.

The inhibitors in urine could affect the growth kinetics process of $\mathrm{CaC}_{2} \mathrm{O}_{4}$ crystallization because the inhibitors not only could reduce the $\mathrm{RS}$ of $\mathrm{CaC}_{2} \mathrm{O}_{4}$ but also could be adsorbed on the surface of $\mathrm{CaC}_{2} \mathrm{O}_{4}$ crystals and close the active growth sites of crystals. The inhibitor could also change the charges and energy distribution on the crystal surface.

For carboxylic acid inhibitors, the number of carboxyl groups $(\mathrm{COOH})$ of the acid will affect its coordination ability ${ }^{11}$ with $\mathrm{Ca}^{2+}$, thus affecting the crystallization kinetics of $\mathrm{CaC}_{2} \mathrm{O}_{4}$. Therefore, the effect of sodium mono-carboxylate ( $\mathrm{NaGly}$ ), di-carboxylate $\left(\mathrm{Na}_{2}\right.$ Tart $)$ and tri-carboxylate $\left(\mathrm{Na}_{3} \mathrm{Cit}\right)$ on the kinetics of $\mathrm{CaC}_{2} \mathrm{O}_{4}$ crystallization was studied by using the electrode method by detecting the change in $\mathrm{Ca}^{2+}$ ions concentration, size, zeta potential, autocorrelation curves and decay time of $\mathrm{CaC}_{2} \mathrm{O}_{4}$ crystallites with reaction time. The reaction order $(\alpha)$ and reaction rate constant $(\mathrm{k})$ were calculated and the mechanism of different carboxylates in inhibiting $\mathrm{CaC}_{2} \mathrm{O}_{4}$ crystallization was discussed.

\section{EXPERIMENTAL}

Sodium glycine (NaGly), sodium tartrate $\left(\mathrm{Na}_{2} \mathrm{Tart}\right)$, sodium citrate $\left(\mathrm{Na}_{3} \mathrm{Cit}\right)$ and other reagents were all in analytical purity. Double distilled water was used. Artificial urine was prepared by $\mathrm{NaCl}(0.106 \mathrm{~mol} / \mathrm{L}), \mathrm{KCl}(0.064 \mathrm{~mol} / \mathrm{L}), \mathrm{NaH}_{2} \mathrm{PO}_{4}$ (0.0032 mol/L), $\mathrm{Na}_{2} \mathrm{SO}_{4}(0.017 \mathrm{~mol} / \mathrm{L}), \mathrm{MgSO}_{4}(0.0038 \mathrm{~mol} / \mathrm{L})$ and $\mathrm{Na}_{3} \mathrm{Cit}(0.0032 \mathrm{~mol} / \mathrm{L})$ [12. Its $\mathrm{pH}$ was adjusted 6 with 0.5 $\mathrm{mol} / \mathrm{L}$ Tris solution.

Saturated $\mathrm{KCl}$ calomel reference electrode (232-type), calcium ion selective electrode (PCa-1 type) and precision $\mathrm{pH}$ meter (PHS-3C) were purchased from Shanghai Precision Scientific Instrument Co. Ltd. The Zetasizer Nano-ZS nanoparticle size analyzer was from Malvern.

Battery, electrode potential and free $\mathrm{Ca}^{2+}$ ion concentration measurement: Calcium ion electrode and calomel electrode were used to compose the measurement battery: $\mathrm{Hg}$, $\mathrm{HgCl}_{2} \mid \mathrm{KCl}$ (saturated) I test solution I sensitive film I $1.0 \mathrm{mM}$ calcium standard solution I Ag, $\mathrm{AgCl}$.

The sensitive film was PVC membrane with di( $p$-isooctyl) phenyl phosphate as an active material. Before use, calcium ion selective electrode was soaked in $1 \mathrm{mmol} / \mathrm{L}$ calcium standard solution to be activated for $24 \mathrm{~h}$ and then cleaned by deionized water to a blank potential value of $-65 \mathrm{mV}$.

Calcium standard curve preparation: After obtaining the $\mathrm{E}$ value corresponding to different concentration of calcium standard solution $\left(\left[\mathrm{Ca}^{2+}\right]\right)$ in the $\mathrm{pH}$ meter, a standard curve was obtained by using $\log \left[\mathrm{Ca}^{2+}\right]$ as abscissa and $\mathrm{E}$ as longitudinal. The linear regression equation was $\mathrm{E}=42.5+27.5$ $\log \left[\mathrm{Ca}^{2+}\right]$ and the correlation coefficient was $\mathrm{R}=0.9992$.
Preparation of $\mathrm{CaC}_{2} \mathrm{O}_{4}$ supersaturation solution: Urine calcium exists in two forms: complexed calcium (e.g., the calcium binded with proteins and the calcium combined with organic acids) and free calcium. However, only free calcium, which is an important factor in stone formation, has physiological activity. According to the literature ${ }^{13,14}$, ionized calcium in the male and female urine were $48.2 \pm 25.5$ and $42.2 \pm 21.1 \mathrm{mg} / \mathrm{L}$ $(1.21 \pm 0.64$ and $1.06 \pm 0.53 \mathrm{mmol} / \mathrm{L})$ and the concentration of $\mathrm{C}_{2} \mathrm{O}_{4}{ }^{2-}$ was $0.53 \pm 0.20 \mathrm{mmol} / \mathrm{L}$. Therefore, the $\mathrm{RS}$ of $\mathrm{CaC}_{2} \mathrm{O}_{4}$ in the male and female urine were $15.25 \pm 10.81$ and $14.21 \pm$ 9.75 , respectively. On the basis of the above $\mathrm{RS}$ range, a $\mathrm{CaC}_{2} \mathrm{O}_{4}$ supersaturated solution of $\left[\mathrm{Ca}^{2+}\right]=\left[\mathrm{C}_{2} \mathrm{O}_{4}{ }^{2-}\right]=0.8 \mathrm{mmol} / \mathrm{L}$ in artificial urine was prepared. According to $\mathrm{K}_{\mathrm{sp}} \mathrm{CaC}_{2} \mathrm{O}_{4)}=2.32$ $\times 10^{-9}$, the RS of these solution was $15.61^{7,14}$.

Crystallization kinetics of $\mathrm{CaC}_{2} \mathbf{O}_{4}$ : About $4.8 \mathrm{~mL}$ of $10 \mathrm{mmol} / \mathrm{L} \mathrm{CaCl}_{2}$ solution was added to $50.4 \mathrm{~mL}$ of $\mathrm{pH} 6$ artificial urinary-Tris solution and $4.8 \mathrm{~mL}$ of $10 \mathrm{mmol} / \mathrm{L}$ $\mathrm{K}_{2} \mathrm{C}_{2} \mathrm{O}_{4}$ solution was quickly added into the mixture. At this time, the supersaturated degree of $\mathrm{CaC}_{2} \mathrm{O}_{4}$ was $\mathrm{RS}=15.61$. After the $\mathrm{E}$ value of free $\mathrm{Ca}^{2+}$ in the solution at different reaction times $(\mathrm{t}=1,5,10,20,40,60 \mathrm{~min})$ was detected, the average concentration of free $\mathrm{Ca}^{2+}$ in the solution was calculated according to the linear regression equation.

The effect of different inhibitors on crystallization kinetics of $\mathrm{CaC}_{2} \mathrm{O}_{4}$ was studied next. NaGly, $\mathrm{Na}_{2}$ Tart, or $\mathrm{Na}_{3}$ Cit was added into the above $\mathrm{CaC}_{2} \mathrm{O}_{4}$ supersaturated solution and the final concentration of carboxylate is $2.0 \mathrm{mmol} / \mathrm{L}$. At different reaction times $(\mathrm{t}=1,5,10,20,40,60 \mathrm{~min}), 1.0 \mathrm{~mL}$ of the reaction mixture was aspirated to detect the particle size, zeta potential, autocorrelation function and decay time of $\mathrm{CaC}_{2} \mathrm{O}_{4}$ crystallites by nanoparticle size analyzer. Diluted hydrochloric acid and diluted $\mathrm{NaOH}$ solution were used to maintain the system $\mathrm{pH}$ (6.0) in the reaction process.

All experiments were repeated three times. The experimental temperature was $(37.0 \pm 0.1)^{\circ} \mathrm{C}$.

\section{RESULTS AND DISCUSSION}

Establishment of kinetic equation of $\mathrm{CaC}_{2} \mathrm{O}_{4}$ crystallization: When $\mathrm{CaC}_{2} \mathrm{O}_{4}$ crystals were precipitated from the system, the free calcium ion concentration $\left[\mathrm{c}\left(\mathrm{Ca}^{2+}\right)\right]$ in the solution decreased. Therefore, the crystallization rate could be studied by detecting the decrease in the rate of $\mathrm{c}\left(\mathrm{Ca}^{2+}\right)$ in the system.

To establish the kinetic equation of $\mathrm{CaC}_{2} \mathrm{O}_{4}$ crystallization according to the equimolar ratio of calcium and oxalate in the supersaturated solution, we assumed that $\mathrm{Ca}^{2+}$ reacted with $\mathrm{C}_{2} \mathrm{O}_{4}{ }^{2-}$ equivalently and the reaction rate (r) equation is as follows:

$$
\mathrm{r}=\mathrm{k}\left[\mathrm{Ca}^{2+}\right]^{\mathrm{p}}\left[\mathrm{Ox}^{2-}\right]^{\mathrm{q}}
$$

Assume that $\mathrm{x}$ is the consumption of $\mathrm{Ca}^{2+}$ or $\mathrm{C}_{2} \mathrm{O}_{4}{ }^{2-}$ at time $\mathrm{t}$ and $\mathrm{p}+\mathrm{q}=\alpha$ because $\left[\mathrm{Ca}^{2+}\right]=\left[\mathrm{C}_{2} \mathrm{O}_{4}{ }^{2-}\right]=\mathrm{c}$. According to the equal-ratio reaction, the arranged eqn. 1 is expressed as follows:

$$
\begin{gathered}
r=\mathrm{kc}^{\alpha}=\mathrm{k}(\mathrm{a}-\mathrm{x})^{\alpha} \\
\text { Because: } \mathrm{r}=-\frac{\mathrm{d}\left[\mathrm{Ca}^{2+}\right]}{\mathrm{dt}}=-\frac{\mathrm{d}[\mathrm{a}-\mathrm{x}]}{\mathrm{dt}}=\frac{\mathrm{dx}}{\mathrm{dt}}
\end{gathered}
$$

By combining (1), (2) and (3) and by taking the logarithmic on both sides of eqn. 3 , we can obtain the following equation: 


$$
\log \mathrm{r}=\log \frac{\mathrm{dx}}{\mathrm{dt}}=\log \mathrm{k}+\alpha \log (\mathrm{a}-\mathrm{x})
$$

where $\mathrm{a}$ and $\mathrm{c}$ in the formula are free $\left[\mathrm{Ca}^{2+}\right](\mathrm{mmol} / \mathrm{L})$ at the initial time $(\mathrm{t}=0)$ and at time $t$ in the solution; $x$ is the consumption amount of $\mathrm{Ca}^{2+}(\mathrm{mmol} / \mathrm{L})$ in the solution at time $\mathrm{t} ; \alpha$ is the reaction order; $\mathrm{k}$ is the reaction rate constant. Eqn. 4 shows a linear relationship between $\log r$ and $\log (\mathrm{a}-\mathrm{x})$. The slope of the line is the reaction order $(\alpha)$ and the intercept is $\log \mathrm{k}$, which could be used to obtain the reaction rate constant $\mathrm{k}$.

Effect of carboxylates on reaction order and reaction rate constant of $\mathrm{CaC}_{2} \mathrm{O}_{4}$ crystallization: We studied the effect of different sodium carboxylate salts on the crystallization kinetics of $\mathrm{CaC}_{2} \mathrm{O}_{4}$, including mono-carboxylate, di-carboxylate and tri-carboxylate (Fig. 1). The log $\left[\mathrm{Ca}^{2+}\right]$ of the system decreased rapidly with the reaction time ranging from 0-20 min (Fig. 1A), which could be caused by the relative supersaturation of the solution being larger at the beginning of the reaction and $\mathrm{CaC}_{2} \mathrm{O}_{4}$ being nucleated abundantly, which led to the rapid decrease in $\left[\mathrm{Ca}^{2+}\right]$. After $20 \mathrm{~min},\left[\mathrm{Ca}^{2+}\right]$ decreased slowly, indicating that the $\mathrm{CaC}_{2} \mathrm{O}_{4}$ of the system was close to precipitation-dissolution equilibrium. After adding $\mathrm{NaGly}$ (Fig. $1 \mathrm{~A}(\mathrm{~b}))$, the amount of free $\left[\mathrm{Ca}^{2+}\right]$ is not significantly different compared with that of the control group. This finding shows that NaGly has little influence on the crystallization kinetics of $\mathrm{CaC}_{2} \mathrm{O}_{4}$.
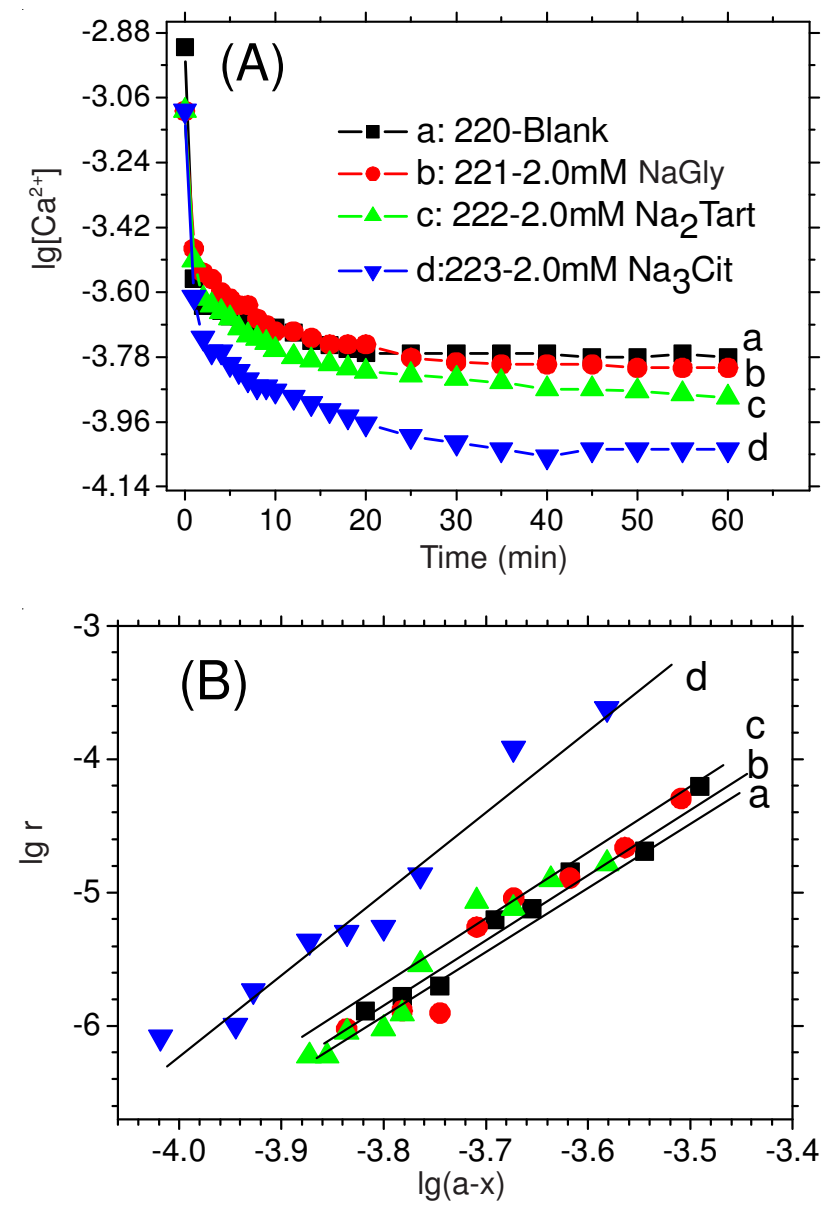

Fig. 1. $\log \left[\mathrm{Ca}^{2+}\right]$-time curve (A) and $\log \mathrm{r}-\log (\mathrm{a}-\mathrm{x})$ curve $(\mathrm{B})$ in $\mathrm{RS}=$ $15.61 \mathrm{CaC}_{2} \mathrm{O}_{4}$ a supersaturated solution in presence of different carboxylic acid inhibitor of $2.0 \mathrm{mmol} / \mathrm{L}$. (a) Blank, (b) NaGly, (c) $\mathrm{Na}_{2}$ Tart, (d) $\mathrm{Na}_{3} \mathrm{Cit}$
After adding $\mathrm{Na}_{2}$ Tart (Fig. $1 \mathrm{~A}(\mathrm{c})$ ), free $\left[\mathrm{Ca}^{2+}\right]$ became smaller than that of the control group and the NaGly group because $\mathrm{Na}_{2}$ Tart is di-carboxylate and can coordinate with $\mathrm{Ca}^{2+}$. When $\mathrm{C}_{2} \mathrm{O}_{4}{ }^{2-}$ chelates with $\mathrm{Ca}^{2+}$ to form $1: 1$ complexes, the stability constant $\left(\mathrm{K}_{\mathrm{s}}\right)$ is $10^{3.0}$. When Tart ${ }^{2-}$ chelates with $\mathrm{Ca}^{2+}$ to form 2:1 complexes, the $\mathrm{K}_{\mathrm{s}}$ is $10^{9.0115}$. The necessary condition to generate $\mathrm{CaC}_{2} \mathrm{O}_{4}$ crystallites in solution is $\left[\mathrm{Ca}^{2+}\right]\left[\mathrm{C}_{2} \mathrm{O}_{4}{ }^{2-}\right] \geq$ $\mathrm{K}_{\mathrm{sp}}$. Adding $2 \mathrm{mmol} / \mathrm{L} \mathrm{Na}_{2}$ Tart into the solution results not only in shifting of the balance of $\mathrm{Ca}^{2+}+\mathrm{C}_{2} \mathrm{O}_{4}{ }^{2-} \rightarrow \mathrm{CaC}_{2} \mathrm{O}_{4}$ to the left, i.e., the $\mathrm{CaC}_{2} \mathrm{O}_{4}$ dissolves, but also in the significant decrease in the free $\left[\mathrm{Ca}^{2+}\right]$ of the system from $1 \mathrm{mmol} / \mathrm{L}$ to $0.165 \mathrm{mmol} / \mathrm{L}$ at $\mathrm{t}=20 \mathrm{~min}$.

The free $\left[\mathrm{Ca}^{2+}\right]$ further decreased when $\mathrm{Na}_{3} \mathrm{Cit}$ was added. $\mathrm{Na}_{3} \mathrm{Cit}$ is a tri-carboxylate and contains three carboxyl and one hydroxyl group, $\mathrm{Na}_{3} \mathrm{Cit}$ can form a ring complex with $\left.\mathrm{Ca}^{2+}\left[\mathrm{Ca}\left(\mathrm{C}_{6} \mathrm{H}_{5} \mathrm{O}_{3}\right)_{2} \cdot 4 \mathrm{H}_{2} \mathrm{O}\right)\right]$ with a five-membered and a sixmembered rings. $\mathrm{Na}_{3} \mathrm{Cit}$ has $\mathrm{K}_{\mathrm{s}}=10^{4.68}$, which is greater than the $\mathrm{K}_{\mathrm{s}}$ of $\mathrm{CaC}_{2} \mathrm{O}_{4}\left(10^{3.0}\right)^{15}$. The solubility of $\mathrm{Ca}\left(\mathrm{C}_{6} \mathrm{H}_{5} \mathrm{O}_{3}\right)_{2} \cdot 4 \mathrm{H}_{2} \mathrm{O}$ is larger in water. Therefore, after $20 \mathrm{~min}$ in the system of $\mathrm{Na}_{3} \mathrm{Cit}$, the free $\left[\mathrm{Ca}^{2+}\right]$ of the system decreases to $0.096 \mathrm{mmol} / \mathrm{L}$, which is less than $0.165 \mathrm{mmol} / \mathrm{L}$ in the presence of $\mathrm{Na}_{2}$ Tart and 0.180 in the presence of NaGly. After adding $2.0 \mathrm{mmol} / \mathrm{L}$ $\mathrm{Na}_{3} \mathrm{Cit}$, we still do not observed any precipitation in the solution even when the reaction time reached $22 \mathrm{~h}$.

According to classical nucleation theory ${ }^{16}$, the nucleation free energy $\Delta \mathrm{G}$ is inversely proportional to the square of $\ln$ RS. With the prolongation of the reaction time, the consumption of $\left[\mathrm{Ca}^{2+}\right]$ in the solution increased rapidly and the relative supersaturation ( $\mathrm{RS}$ ) of $\mathrm{CaC}_{2} \mathrm{O}_{4}$ was reduced. Thus, the nucleation energy barrier $\Delta \mathrm{G}$ of $\mathrm{CaC}_{2} \mathrm{O}_{4}$ gradually increased, which results in difficulty of $\mathrm{CaC}_{2} \mathrm{O}_{4}$ to form nucleation.

By using the differential method, we plotted the reaction time (t) to $\mathrm{Ca}^{2+}$ consumption $\left[\mathrm{x}\left(\mathrm{Ca}^{2+}\right)\right]$. The slope of any point of the curve (derived from the origin data analysis software) was the rate of the reaction $r$. We then plotted with $\log r$ to $\log (\mathrm{a}-\mathrm{x})$ (Fig. 1B), in which the slope of the straight line was the reaction order $(\alpha)$; the reaction rate constant $\mathrm{k}$ was obtained through the intercept $(\log \mathrm{k})$. The results are shown in Table-1.

\begin{tabular}{|c|c|c|c|c|}
\hline \multicolumn{5}{|c|}{$\begin{array}{l}\text { AVERAGE REACTION ORDERS }(\bar{\alpha}) \text { AND RATE } \\
\text { CONSTANTS }(\overline{\mathrm{k}}) \mathrm{OF} \mathrm{CaC}_{2} \mathrm{O}_{4} \text { A CRYSTALLIZATION IN } \\
\text { PRESENCE OF THREE DIFFERENT CARBOXYLATES* }\end{array}$} \\
\hline \multirow{2}{*}{ Inhibitor } & \multicolumn{2}{|c|}{ In artificial urine } & \multicolumn{2}{|c|}{ In saline system } \\
\hline & $\overline{\mathrm{k}}$ & $\bar{\alpha}$ & $\overline{\mathrm{k}}$ & $\bar{\alpha}$ \\
\hline Blank & $0.99 \times 10^{9}$ & 3.3 & $3.1 \times 10^{9}$ & 3.3 \\
\hline NaGly & $1.68 \times 10^{7}$ & 3.4 & $2.0 \times 10^{7}$ & 3.3 \\
\hline $\mathrm{Na}_{2}$ Tart & $9.76 \times 10^{5}$ & 3.4 & $2.0 \times 10^{6}$ & 3.1 \\
\hline $\mathrm{Na}_{3}$ cit & $2.29 \times 10^{5}$ & 3.4 & $1.0 \times 10^{6}$ & 3.1 \\
\hline
\end{tabular}

Fig. 1B is the relational graph of $\log r-\log (a-x)$ in the $\mathrm{CaC}_{2} \mathrm{O}_{4}$ supra-saturated solution in presence of $2 \mathrm{mmol} / \mathrm{L}$ NaGly, $\mathrm{Na}_{2}$ Tart, or $\mathrm{Na}_{3} \mathrm{Cit}$ and $\mathrm{RS}=15.61 . \overline{\mathrm{k}}$ reduced from $0.99 \times 10^{9}-1.68 \times 10^{7}, 9.76 \times 10^{5}$ and $2.29 \times 10^{5}$ after adding $\mathrm{NaGly}, \mathrm{Na}_{2}$ Tart, or $\mathrm{Na}_{3} \mathrm{Cit}$, respectively, in the artificial urinary system (Table-1). However, the addition of these solutions had 
little effect on the reaction order $(\alpha)$ and average reaction order $\bar{\alpha}=3.4$. This finding shows that $\mathrm{NaGly}, \mathrm{Na}_{2}$ Tart and $\mathrm{Na}_{3} \mathrm{Cit}$ participate in the crystallization kinetics of $\mathrm{CaC}_{2} \mathrm{O}_{4}$ in a certain extent and has an influence on this process. $\overline{\mathrm{k}}$ value could directly reflect the speed of reaction rate and is related with the reaction process. When two $\mathrm{CaC}_{2} \mathrm{O}_{4}$ molecules collide with each other, the $\mathrm{CaC}_{2} \mathrm{O}_{4}$ molecules win an energy. However, time is still needed to transfer energy internal molecules to make the weakest bond fractured. If the $\mathrm{CaC}_{2} \mathrm{O}_{4}$ molecule collides with other molecule in the system (for example, the inhibitor molecules), the $\mathrm{CaC}_{2} \mathrm{O}_{4}$ will lose the activation energy and an invalid collision will occur. Thus, the crystallization process of $\mathrm{CaC}_{2} \mathrm{O}_{4}$ is inhibited in the presence of carboxylate inhibitors.

Effect of carboxylates on particle size of $\mathrm{CaC}_{2} \mathrm{O}_{4}$ in crystallization process: Fig. 2 shows the change of particle size, zeta and autocorrelation decay time of $\mathrm{CaC}_{2} \mathrm{O}_{4}$ crystallites in presence of $2 \mathrm{mmol} / \mathrm{L}$ of NaGly, $\mathrm{Na}_{2}$ Tart and $\mathrm{Na}_{3} \mathrm{Cit}$, respectively, in the artificial urine. The figure shows that the crystallite size increased gradually within $1 \mathrm{~min}$ to $20 \mathrm{~min}$ and reached the maximum at $20 \mathrm{~min}(1070,949$ and $567 \mathrm{~nm}$, respectively). The crystallite size then decreased slightly (Fig. 2A).

The RS of the system decreased from 15.61 to $7.28,6.54$ and 5.27 in $\mathrm{t}=20 \mathrm{~min}$ after adding $\mathrm{NaGly}, \mathrm{Na}_{2}$ Tart, or $\mathrm{Na}_{3} \mathrm{Cit}$, respectively. By using the Weimarn experience formula, the dispersion degree $(\mathrm{R})$ of crystallites can be expressed as follows:

$$
\mathrm{R}=\mathrm{K} \times \frac{(\mathrm{Q}-\mathrm{s})}{\mathrm{s}}
$$

where Q is the concentration of the precipitated substance at the moment of adding the precipitator, $s$ is the solubility of the precipitated substance at the moment of precipitation, (Q-s) is the instantaneous supersaturation at the beginning of precipitation, (Q-s)/s is the relative saturation (RS) at the moment of precipitation and $\mathrm{K}$ is a constant.

The formula (5) shows that the greater the relative saturation of the solution (RS) and the larger its dispersion degree $(\mathrm{R})$, the smaller the particles of precipitation and vice versa. Given the decrease in RS in the solutions, the dispersion (R) of crystallites also decreased. Therefore, the crystallite size of $\mathrm{CaC}_{2} \mathrm{O}_{4}$ in the solution increased, which made the particle size increase from 846, 619 and $324 \mathrm{~nm}$ to 1070,949 and $567 \mathrm{~nm}$, respectively.

The formation and dissolution of crystals in the solution is a dynamic equilibrium process. The crystallite size slightly decreased after $20 \mathrm{~min}$, which could be caused by the fact that artificial urine contains much electrolytes $(\mathrm{NaCl}, \mathrm{KCl}$, etc.). These electrolytes could increase the solubility of $\mathrm{CaC}_{2} \mathrm{O}_{4}$ crystallites and make $\mathrm{CaC}_{2} \mathrm{O}_{4}$ crystallite partially dissolved. The $\mathrm{Cit}^{3-}$ and $\mathrm{Tart}^{2-}$ in the system could also inhibit the growth of $\mathrm{CaC}_{2} \mathrm{O}_{4}$ crystallites. In addition, the zeta potential of $\mathrm{CaC}_{2} \mathrm{O}_{4}$ crystallites becomes more negative after $20 \mathrm{~min}$ (Fig. 2B). The electrostatic repulsion force of the crystallites also increased, inhibiting the aggregation of crystallites and decrease in the size of crystallites.

At $\mathrm{t}=5,10,20,40,60 \mathrm{~min}$, the size of the formed $\mathrm{CaC}_{2} \mathrm{O}_{4}$ crystallites in presence of different inhibitors can be arranged in the following order: $\mathrm{Na}_{3} \mathrm{Cit}<\mathrm{Na}_{2}$ Tart $<\mathrm{NaGly} \approx$ Blank.
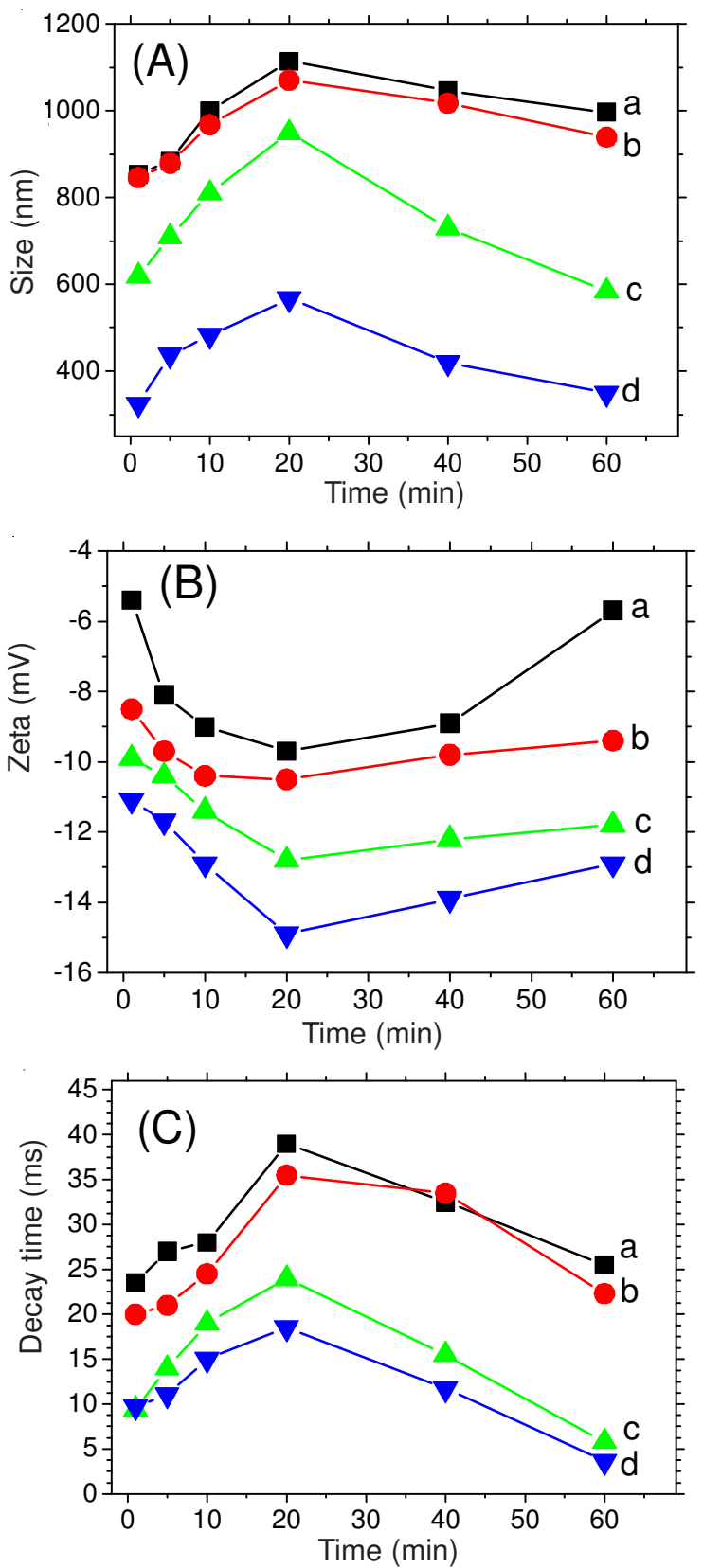

Fig. 2. Property changes of $\mathrm{CaC}_{2} \mathrm{O}_{4}$ crystallites with reaction time in presence of $2.0 \mathrm{mmol} / \mathrm{L}$ of $\mathrm{NaGly}, \mathrm{Na}_{2}$ Tart and $\mathrm{Na}_{3} \mathrm{Cit}$ in artificial urine: (A) crystallite size, (B) zeta potential and (C) autocorrelation decay time. (a) Blank, (b) NaGly, (c) $\mathrm{Na}_{2}$ Tart, (d) $\mathrm{Na}_{3}$ Cit. (RS = 15.61)

This order shows that $\mathrm{Na}_{3} \mathrm{Cit}$ has a greater ability than $\mathrm{Na}_{2}$ Tart and NaGly in the inhibition of nucleation, growth and aggregation of $\mathrm{CaC}_{2} \mathrm{O}_{4}$ crystallites. $\mathrm{Cit}^{3-}$ complexed with $\mathrm{Ca}^{2+}$ to form complex $\mathrm{Ca}\left(\mathrm{C}_{6} \mathrm{H}_{5} \mathrm{O}_{3}\right)_{2} \cdot 4 \mathrm{H}_{2} \mathrm{O}$ and the solubility of the complex was $0.096 \mathrm{~g}$, greater than that of $\mathrm{CaC}_{2} \mathrm{O}_{4}(0.004 \mathrm{~g}) . \mathrm{K}_{\mathrm{s}}=10^{9.01}$ when $\operatorname{tart}^{2-}$ and $\mathrm{Ca}^{2+}$ formed a 2:1 complex ${ }^{15}$, thus making the balance of $\mathrm{Ca}^{2+}+\mathrm{C}_{2} \mathrm{O}_{4}{ }^{2-} \rightleftharpoons \mathrm{CaC}_{2} \mathrm{O}_{4}$ shift to the left, i.e., $\mathrm{CaC}_{2} \mathrm{O}_{4}$ crystallite will be dissolved. However, NaGly is monocarboxylate and its complexing capacity with $\mathrm{Ca}^{2+}$ is smaller than that of $\mathrm{Na}_{2}$ Tart and $\mathrm{Na}_{3} \mathrm{Cit}$. Therefore, the size of $\mathrm{CaC}_{2} \mathrm{O}_{4}$ crystallites formed in the presence of $\mathrm{NaGly}$ has no significant difference compared with that of the control group. This finding also shows that $\mathrm{NaGly}$ has less effect on the crystallization kinetics of $\mathrm{CaC}_{2} \mathrm{O}_{4}$. 
The growth of urine crystallite is a slow process and urine crystallite is difficult to grow into pathological size in a short time when urine flows through the tubular. According to Reid and Finlayson ${ }^{17}$, the separated $\mathrm{CaC}_{2} \mathrm{O}_{4}$ crystals are excreted from the body through urine before the crystals to become large enough to become fixed on the tubule. Therefore, by calculating the required time of nucleation and growth of an independent crystal, they denoted that $\mathrm{CaC}_{2} \mathrm{O}_{4}$ crystals are impossible to form urinary stones. However, urinary crystallite can agglomerate quickly in a short time. Thus, its size could increase rapidly in a short time ${ }^{9}$. Therefore, the ability of affecting the formation of urinary stone in a descending order is as follows: agglomeration $>$ nucleation $>$ growth.

Effect of carboxylates on zeta potential of $\mathrm{CaC}_{2} \mathrm{O}_{4}$ crystallites: Two types of interaction force exist between two separated particles: electrostatic repulsion force $\left(\mathrm{W}_{\mathrm{R}}\right)$ and Van der Waals' force $\left(\mathrm{W}_{\mathrm{A}}\right)^{18}$. Given that $\mathrm{W}_{\mathrm{R}}$ is a repulsive force and $\mathrm{W}_{\mathrm{A}}$ is an attractive force, the total potential energy $\left(\mathrm{W}_{\mathrm{T}}\right)$ in the interaction between two particles is as follows:

$$
\mathrm{W}_{\mathrm{T}}=\mathrm{W}_{\mathrm{A}}-\mathrm{W}_{\mathrm{R}}
$$

when $\mathrm{W}_{\mathrm{A}}>\mathrm{W}_{\mathrm{R}}$, the total potential energy $\mathrm{W}_{\mathrm{T}}>0$ and crystals tend to agglomerate; when $\mathrm{W}_{\mathrm{T}}<0$, the crystals will disperse instead of agglomerating. $\mathrm{W}_{\mathrm{R}}$ is closely related to the surface charges of particles. According to the colloidal theory established by Nernst-Stern-Gouy, the electric double layer can be formed on the charged particle surface between liquid and solid phases and the electric potential difference can be expressed by the zeta potential. A higher concentration of anions in the solution results in a stronger absorption force of the crystallites and the more anions are adsorbed onto the particle surface. The charge density also increases and the zeta potential becomes more negative. The repulsive force $\mathrm{W}_{\mathrm{R}}$ also increases.

Fig. 2B shows that the absolute value of the zeta potential of $\mathrm{CaC}_{2} \mathrm{O}_{4}$ crystallites increased first in different systems and then decreased. The zeta potential reached maximum value at $20 \mathrm{~min}$, which were $-10.5,-12.8$ and $-14.9 \mathrm{mV}$ in the presence of $2.0 \mathrm{mmol} / \mathrm{L}$ of $\mathrm{NaGly}, \mathrm{Na}_{2}$ Tart and $\mathrm{Na}_{3} \mathrm{Cit}$ respectively. These values are all smaller than that of the control group $(-9.7 \mathrm{mV})$. This finding indicates that the repulsive force of $\mathrm{CaC}_{2} \mathrm{O}_{4}$ crystallites in presence of inhibitors is larger than that of the control and the $\mathrm{CaC}_{2} \mathrm{O}_{4}$ crystallites formed in the presence of inhibitors are more dispersed than those of the controls. At the same reaction time, the absolute value of Zeta potential of $\mathrm{CaC}_{2} \mathrm{O}_{4}$ crystallites in the presence of various inhibitor follows the order: $\mathrm{Na}_{3} \mathrm{Cit}>\mathrm{Na}_{2}$ Tart $>\mathrm{NaGly}>$ controls.

Comparison of system stability after adding different carboxylates: In a stable colloidal system, the light intensity autocorrelation curve is a smooth exponential decay curve at an autocorrelation decay time $\left(\Gamma_{\mathrm{a}}\right)^{19}$. The decay rate of the light intensity autocorrelation function is inversely proportional to the particle diameter (d), that is, the smaller the particle diameter is, the quicker the decay of autocorrelation curve is and the shorter the $\Gamma_{\mathrm{a}}$ is. On the contrary, the larger the particle diameter is, the slower the decay of autocorrelation curve is and the longer the $\Gamma_{\mathrm{a}}$ is.

Fig. 2C shows the variation of $\Gamma_{\mathrm{a}}$ in the presence of 2.0 $\mathrm{mmol} / \mathrm{L}$ of $\mathrm{NaGly}, \mathrm{Na}_{2}$ Tart and $\mathrm{Na}_{3} \mathrm{Cit}$. $\Gamma_{\mathrm{a}}$ gradually increased within 1-20 min and reached the maximum at $20 \mathrm{~min}$, in which $\Gamma_{\mathrm{a}}=35.5,24$ and $18.5 \mathrm{~ms}$, respectively. This result shows that the crystallite size continuously increased. The decrease slightly in $\Gamma_{\mathrm{a}}$ after $20 \mathrm{~min}$ indicated a decrease of the crystallite size. This result is consistent with the variation of the size of the crystallites in Fig. 2(A).

Fig. 3 shows the changes of the autocorrelation decay curves of $\mathrm{CaC}_{2} \mathrm{O}_{4}$ crystallites after adding $2.0 \mathrm{mmol} / \mathrm{L} \mathrm{Na}_{2}$ Tart into $\mathrm{CaC}_{2} \mathrm{O}_{4}$ supersaturated solution. These autocorrelation curves are un-smooth decay curves, indicating the larger change of crystallite particle sizes in the system, that is, the system is unstable. Within 1-20 min, the autocorrelation curve in the range of $\Gamma_{\mathrm{a}}=9.4-24 \mathrm{~ms}$ showed many small bumps (Fig. 3a-d). This bumps occurred because the $\mathrm{CaC}_{2} \mathrm{O}_{4}$ microcrystallites continued to increase. Fig. 2A shows that the particle size increased from $619 \mathrm{~mm}$ to $949 \mathrm{~nm}$. After $20 \mathrm{~min}$ (Fig. 3e-f), although the autocorrelation curves still had small bulges, the curves were smoother compared with that before $20 \mathrm{~min}$ (Fig. 3a-c). $\Gamma_{\mathrm{a}}$ decreased from $24 \mathrm{~ms}$ at $\mathrm{t}=20 \mathrm{~min}$ to $5.8 \mathrm{~ms}$ at $\mathrm{t}=60 \mathrm{~min}$. This finding denotes that the system tends to be stabilized gradually.

The effect of different inhibitors on light intensity autocorrelation curve is different. $\Gamma_{\mathrm{a}}$ of crystallite after adding $\mathrm{Na}_{3} \mathrm{Cit}$ was significantly less than that after adding $\mathrm{Na}_{2}$ Tart, $\mathrm{NaGly}$ and the control. The particle size of $\mathrm{CaC}_{2} \mathrm{O}_{4}$ crystallite formed in the presence of $2.0 \mathrm{mmol} / \mathrm{L} \mathrm{Na}_{3} \mathrm{C}$ was smaller than that in the presence of $\mathrm{Na}_{2}$ Tart, NaGly, or the control. The inhibition ability of $\mathrm{Na}_{3} \mathrm{Cit}$ to the growth and aggregation of $\mathrm{CaC}_{2} \mathrm{O}_{4}$ crystallite was stronger than that of $\mathrm{Na}_{2}$ Tart and NaGly. The following properties enable $\mathrm{Na}_{2}$ Tart and $\mathrm{Na}_{3} \mathrm{Cit}$ to inhibit the growth of $\mathrm{CaC}_{2} \mathrm{O}_{4}$ : These carboxylates can attach on the active growth sites of $\mathrm{CaC}_{2} \mathrm{O}_{4}$ crystallites, thereby restraining the growth and aggregation of $\mathrm{CaC}_{2} \mathrm{O}_{4}$ crystallites. Specifically, $\mathrm{Cit}^{3-}$ and $\mathrm{Tart}^{2-}$ have more than two carboxyl groups and more than one hydroxyl group and the distance between the two carboxyl groups is equal to the length of three $\mathrm{C}-\mathrm{C}$ bonds. This molecular structure makes these carboxylates strongly absorbed on the surface of $\mathrm{CaC}_{2} \mathrm{O}_{4}$ crystallites $^{20-22}$. This structure not only prevents $\mathrm{Ox}^{2-}$ from migrating to the crystal surface, thus inhibiting crystal growth, but also makes the negative charges on the crystallite surface and the repulsive force between crystals to increase, thus inhibiting crystallite aggregation. Given that oxalic acid is a binary weak acid, the acid effect of $\mathrm{H}_{2} \mathrm{Ox}$ on the crystallization kinetics of $\mathrm{CaC}_{2} \mathrm{O}_{4}$ cannot be ignored. The following chemical balances exist in the supersaturated solution of $\mathrm{CaC}_{2} \mathrm{O}_{4}$ :

$$
\begin{gathered}
\mathrm{CaC}_{2} \mathrm{O}_{4} \rightleftharpoons \mathrm{Ca}^{2+}+\mathrm{C}_{2} \mathrm{O}_{4}^{2-} \\
\mathrm{C}_{2} \mathrm{O}_{4}{ }^{2-} \stackrel{\mathrm{H}^{+}}{\rightleftharpoons} \mathrm{HC}_{2} \mathrm{O}_{4}^{-} \stackrel{\mathrm{H}^{+}}{\rightleftharpoons} \mathrm{H}_{2} \mathrm{C}_{2} \mathrm{O}_{4}
\end{gathered}
$$

Considering that $\mathrm{H}^{+}$can combine with $\mathrm{Ox}^{2-}$ in the solution to form $\mathrm{HC}_{2} \mathrm{O}_{4}^{-}$, the $\mathrm{C}_{2} \mathrm{O}_{4}{ }^{2-}$ concentration decreases and the reaction of $\mathrm{Ca}^{2+}+\mathrm{C}_{2} \mathrm{O}_{4}{ }^{2-} \rightleftharpoons \mathrm{CaC}_{2} \mathrm{O}_{4}$ moves to left. Therefore, $\mathrm{CaC}_{2} \mathrm{O}_{4}$ crystallites are slowly dissolved and the particle size gradually decreases. Thus, the weak acidic environment (pH 6) in this experiment is beneficial to restrain the formation of $\mathrm{CaC}_{2} \mathrm{O}_{4}$ crystallites.

\section{Conclusion}

The crystallization kinetics of $\mathrm{CaC}_{2} \mathrm{O}_{4}$ and the effects of monocarboxylate NaGly, dicarboxylate $\mathrm{Na}_{2}$ Tart and tricar- 


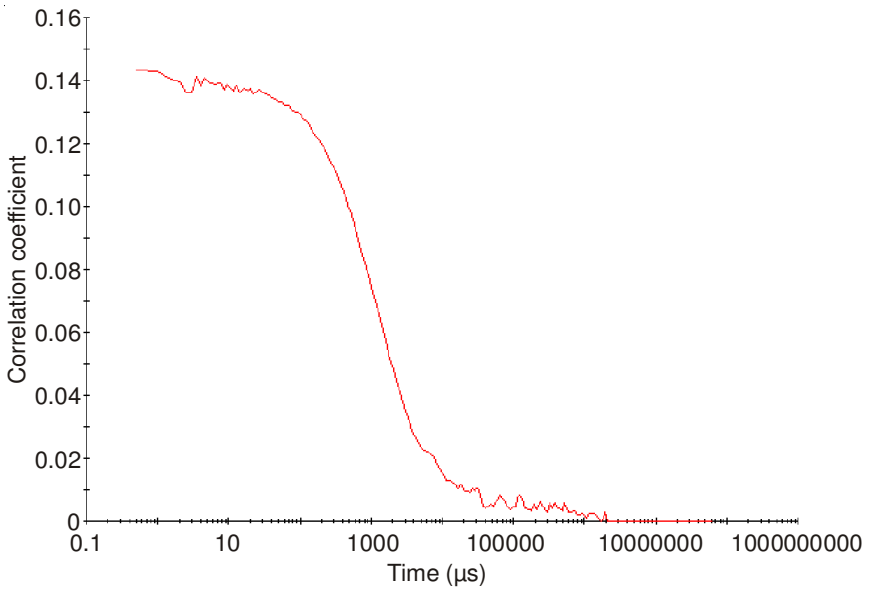

(a) $1 \mathrm{~min}$

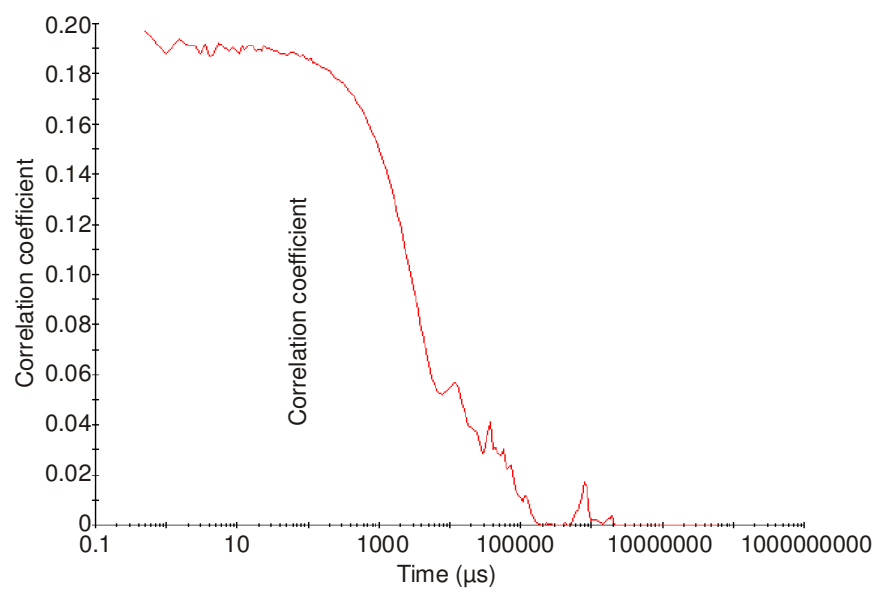

(c) $10 \mathrm{~min}$

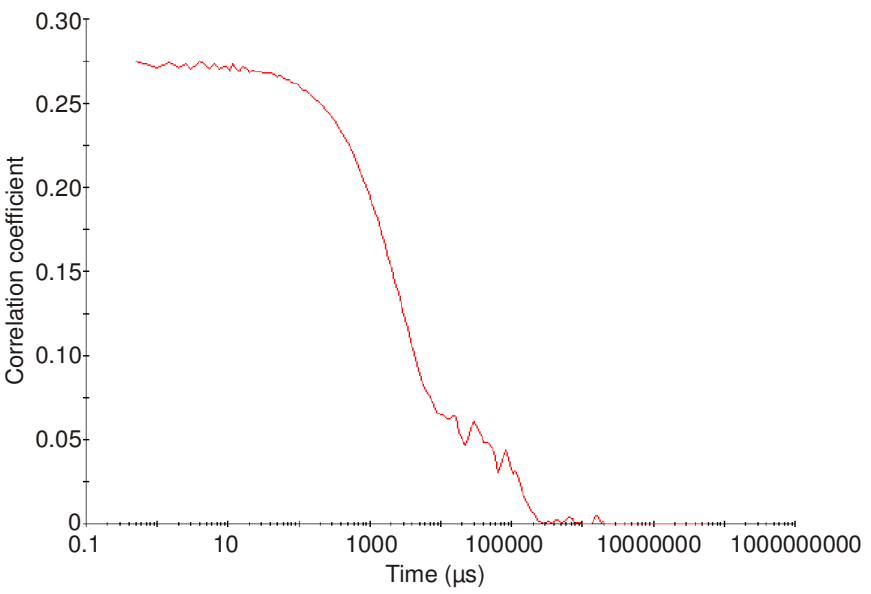

(b) $5 \mathrm{~min}$

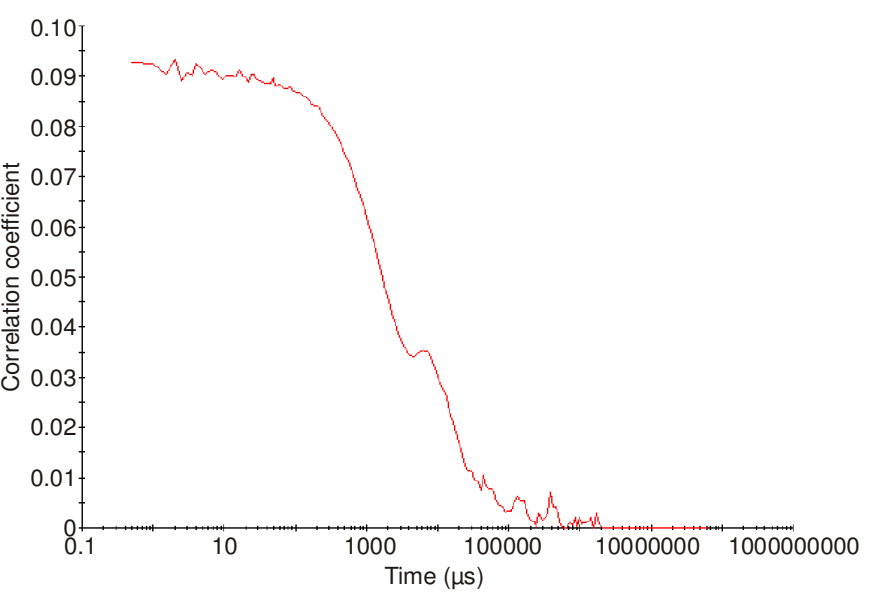

(d) $20 \mathrm{~min}$

Fig. 3. Autocorrelation decay curves of $\mathrm{CaOxa}$ crystallites over reaction time in $\mathrm{RS}=15.61 \mathrm{CaOxa}$ supersaturated solution in the presence of 2.0 mmol/L $\mathrm{Na}_{2}$ Tart. (a)1; (b) 5; (c) 10; (d) 20; (e) 40; (f) $60 \mathrm{~min}$

boxylate $\mathrm{Na}_{3} \mathrm{Cit}$ in artificial urine were studied. In the absence of an inhibitor, the crystallization kinetics equation of $\mathrm{CaC}_{2} \mathrm{O}_{4}$ is $\mathrm{r}=\mathrm{kc}^{3.3}$, the average reaction order is $\bar{\alpha}=3.3$ and the average reaction rate constant is $\overline{\mathrm{k}}=0.99 \times 10^{9}$. When NaGly, $\mathrm{Na}_{2}$ Tart and $\mathrm{Na}_{3}$ Cit were added, no significant effect exist on $\bar{\alpha}$, but $\overline{\mathrm{k}}$ reduced to $1.68 \times 10^{7}, 9.76 \times 10^{5}$ and $2.29 \times 10^{5}$, respectively, indicating that these carboxylates could reduce the reaction rate of $\mathrm{CaC}_{2} \mathrm{O}_{4}$ crystallization. The addition of different carboxylates could change the particle size, zeta potential and autocorrelation decay time of $\mathrm{CaC}_{2} \mathrm{O}_{4}$ crystallites. The more the number of carboxyl groups in carboxylates, the stronger the ability of the acid to inhibit the nucleation, growth and aggregation of $\mathrm{CaC}_{2} \mathrm{O}_{4}$ crystallites. The inhibiting ability of different sodium carboxylate follows the order $\mathrm{Na}_{3} \mathrm{Cit}>$ $\mathrm{Na}_{2}$ Tart $>$ NaGly $>$ controls.

\section{ACKNOWLEDGEMENTS}

This research work was supported by the Natural Science Foundation of China (81170649 and 30672103).

\section{REFERENCES}

1. T. Jung, J.N. Kim, W.S. Kim and C.K. Choi, J. Cryst. Growth, 327, 167 (2011).

2. A.H. Mangood, M.M. Seif and S.M. Hamza, Asian J. Chem., 22, 7257 (2010).
3. S. Zhang and Z.-X. Su, Biol. Appl., 32, 840 (2012).

4. S. Atanassova, J. Cryst. Growth, 312, 1940 (2010).

5. H. Peng, J.-M. Ouyang, X.-Q. Yao and R.-E. Yang, Int. J. Nanomed., 7, 4727 (2012).

6. S. Nishio, M. Hatanaka, H. Takeda, K. Aoki, T. Iseda, H. Iwata and M. Yokoyama, Int. J. Urol., 8, S58 (2001).

7. L. Wang, X. Guan, R. Tang, J.R. Hoyer, A. Wierzbicki, J.J. De Yoreo and G.H. Nancollas, J. Phys. Chem. B, 112, 9151 (2008).

8. M. Carvalho and M.A. Vieira, Int. Braz. J. Urol., 30, 205 (2004).

9. M. Beghalia, S. Ghalem, H. Allalia, A. Belouatek and A. Marouf, Asian J. Chem., 21, 1119 (2009).

10. P.B. Patel and K.R. Vadalia, J. Chem. Pharm. Res., 3, 491 (2011).

11. J. Yang, J.J. Li, H.X. Yuan and J.M. Ouyang, J. Inorg. Mater, 25, 1185 (2010).

12. F.J. Opalko, J.H. Adair and S.R. Khan, J. Cryst. Growth, 181, 410 (1997).

13. T. Lee and Y.C. Lin, Cryst. Growth Des., 11, 2973 (2011).

14. W.G. Robertson, Nephron, Physiol., 98, 21 (2004).

15. J.A. Dean and H. McGraw, Lange's Handbook of Chemistry, Science press (1991).

16. S. Auer and D. Frenkel, Nature, 409, 1020 (2001).

17. B. Finlayson and F. Reid, Invest. Urol., 15, 442 (1978).

18. E.R. Boevé, L.C. Cao, W.C. De Bruijn, W.G. Robertson, J.C. Romijn and F.H. Schröder, J. Urol., 152, 531 (1994).

19. H. Schnablegger and O. Glatter, Appl. Opt., 30, 4889 (1991).

20. M.L. Weaver, S.R. Qiu, J.R. Hoyer, W.H. Casey, G.H. Nancollas and J.J. De Yoreo, J. Cryst. Growth, 306, 135 (2007).

21. S.R. Qiu, A. Wierzbicki, C.A. Orme, A.M. Cody, J.R. Hoyer, G.H. Nancollas, S. Zepeda and J.J.D. Yoreo, Proc. Nat. Acad. Sci. USA, 101, 1811 (2004).

22. A.M. Cody and R.D. Cody, J. Cryst. Growth, 135, 235 (1994) 